\title{
Nobel goes to T-cell pioneers whose work 'changed face of immunology'
}

London. The 1996 Nobel prize for physiology or medicine has been awarded to two immunologists for a pioneering discovery, made more than two decades ago, of the way in which the immune system recognizes virus-infected cells.

The award has been made to Peter C. Doherty, adjunct professor of pathology and paediatrics at the University of Tennessee College of Medicine, and Rolf M. Zinkernagel, head of the institute of immunology at the University of Zurich in Switzerland. It comes as belated recognition for research that had an immediate impact on immunology, and has since paved the way for improved understanding of infectious diseases and chronic inflammatory conditions, such as diabetes and multiple sclerosis.

The Nobel prize is the second award to have been won by the scientists in consecutive years for a discovery that was initially published in April 1974 (see Nature 248, 701; 1974) and built upon in October of the same year (see Nature 251, 547; 1974). They won the 1995 Albert Lasker Medical Research Award for the same work - reinforcing its reputation as a Nobel 'precursor'.

Their peers were quick to congratulate both scientists as worthy winners who should have been recognized by the Nobel academy earlier. "It's about time," says Polly Matzinger, an immunologist at the National Institutes of Health in Maryland. The research, she adds, "changed the face of immunology. [The award] is wonderful".

Hidde Ploegh, professor of biology at the Massachusetts Institute of Technology, says that "there had never been any question about the importance of this landmark discovery", which provided the direction for

\section{Rise in US research spending approved}

Washington. Spending by the US government on research and development will grow substantially next year for the first time in four years, rising from $\$ 71$ billion to $\$ 74$ billion. The 4.1 per cent increase is contained in spending bills hurriedly agreed by Congress and President Bill Clinton early last week.

According to an assessment by the American Association for the Advancement of Science, basic research will fare less well than applied research and development, with an overall increase of 2.7 per cent.

NATURE $\cdot$ VOL $383 \cdot 10$ OCTOBER 1996
$\&$ without harming healthy cells.

They also knew that the complicated and intricate job of protecting the body from infection was carried out by T- and B-lymphocyte cells. Researchers had determined that antibodies produced by B-lymphocytes could recognize and eliminate microorganisms, such as bacteria. While it was known how T-cells could reject tissue transplants following recognition of molecules known as major histocompatibility antigens, how these cells recognized virus-infected cells was unclear.

Jonathan Howard, a geneticist at the University of Cologne, says that Doherty and Zinkernagel clarified the role of histocompatibility antigens by using real viruses and set the agenda for the next ten years of

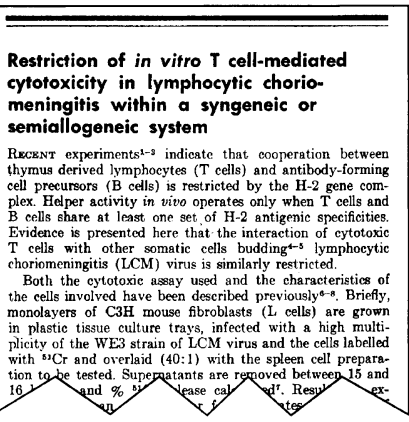
research. The breakthrough came when they carried out experiments designed to investigate how T-lymphocytes protect mice against infection from a virus able to cause meningitis.

Mice were infected with the virus and developed virus-killing T-lymphocytes. But, unexpectedly, the scientists found that these T-lymphocytes were unable to kill

future research into the structure and biochemistry of T-cell immunology.

One immunologist, who performed important follow-up experiments, says the prize is "absolutely terrific" news. "I am very lucky to have been totally inspired by their work," says Alain Townsend, professor of immunology at the John Radcliffe Hospital, Oxford, and author of research in the immunology of the influenza virus in the early 1980s. "I used to refer to Rolf [Zinkernagel] as the Bach of immunology."

Doherty was born in 1940 in Australia, where he completed his masters degree. In 1970 he completed a PhD at the University of Edinburgh in Scotland, and joined the John Curtin School of Medical Research in Canberra two years later.

Zinkernagel was born in Switzerland in 1944. He completed his MD thesis at the University of Basel in 1970, and was still a postgraduate research student, not yet having completed his $\mathrm{PhD}$, when he submitted with Doherty the Nobel-winning research to Nature in December 1973.

Immunologists at the time knew that lymphocyte cells were capable of destroying foreign, invading, microorganisms as well as the body's own infected cells, but somehow virus-infected cells from other strains of mice, demonstrating that an individual mouse's T-cells remain ineffective unless they can also recognize the major histocompatibility antigens of the infected cells.

The findings immediately opened up several doors to research into the ability of the body's immune system to recognize and react to microorganisms other than viruses. Further research using a range of molecular tools has since confirmed Doherty and Zinkernagel's original models, and has added important structural detail to their more general picture.

Immunologists now know more about the body's histocompatibility antigens, whose cating viruses. They have worked out that T-cells recognize a small part of the invading virus - a peptide - that sticks to the body's histocompatibility antigens. Such research has important implications for the development of vaccines.

"This Nobel prize is very appropriate," says Jonathan Sprent, an immunologist at the Scripps Research Institute, La Jolla, California. "So much of immunology is based on what they [Doherty and Zinkernagel] did." Ehsan Masood \& Ursula Weiss recognition by T-cells is important for eradi- 